\title{
Characteristics of trace metals in traffic-derived particles in Hsuehshan Tunnel, Taiwan: size distribution, potential source, and fingerprinting metal ratio
}

\author{
Y.-C. Lin ${ }^{1}$, C.-J. Tsai ${ }^{2}$, Y.-C. Wu ${ }^{3}$, R. Zhang ${ }^{4}$, K.-H. Chi ${ }^{5}$, Y.-T. Huang ${ }^{1}$, S.-H. Lin ${ }^{1}$, and S.-C. Hsu ${ }^{1, \dagger}$ \\ ${ }^{1}$ Research Center for Environmental Changes, Academia Sinica, Nankang, Taipei, 115, Taiwan \\ ${ }^{2}$ Institute of Environmental Engineering, National Chiao Tung University, Hsinchu, 300, Taiwan \\ ${ }^{3}$ Environmental Analysis Laboratory, Environmental Protection Administration, Executive Yuan, 320, Taiwan \\ ${ }^{4}$ Key Laboratory of Regional Climate-Environment Research for Temperate East Asia, \\ Institute of Atmospheric Physics, Chinese Academy of Sciences, Beijing, China \\ ${ }^{5}$ Institute of Environmental and Occupational Health Sciences, National Yang Ming University, Taipei 112, Taiwan \\ $\dagger$ deceased
}

Correspondence to: Y.-C. Lin (yclin26@rcec.sinica.edu.tw)

Received: 5 May 2014 - Published in Atmos. Chem. Phys. Discuss.: 28 May 2014

Revised: 19 March 2015 - Accepted: 25 March 2015 - Published: 21 April 2015

\begin{abstract}
Traffic emissions are a significant source of airborne particulate matter (PM) in ambient environments. These emissions contain an abundance of toxic metals and thus pose adverse effects on human health. Size-fractionated aerosol samples were collected from May to September 2013 by using micro-orifice uniform deposited impactors (MOUDIs). Sample collection was conducted simultaneously at the inlet and outlet sites of Hsuehshan Tunnel in northern Taiwan, which is the second-longest freeway tunnel $(12.9 \mathrm{~km})$ in Asia. This endeavor aims to characterize the chemical constituents and size distributions, as well as fingerprinting ratios of particulate metals emitted by vehicle fleets. A total of 36 metals in size-resolved aerosols were determined through inductively coupled plasma mass spectrometry. Three major groups - namely, tailpipe emissions $(\mathrm{Zn}, \mathrm{Pb}$, and $\mathrm{V}$ in fine mode), wear debris $(\mathrm{Cu}, \mathrm{Cd}, \mathrm{Fe}$, $\mathrm{Ga}, \mathrm{Mn}, \mathrm{Mo}, \mathrm{Sb}$, and $\mathrm{Sn})$, and resuspended dust $(\mathrm{Ca}, \mathrm{Mg}$, $\mathrm{K}$, and $\mathrm{Rb}$ ) - of airborne $\mathrm{PM}$ metals were categorized on the basis of the results of enrichment factor, correlation matrix, and principal component analysis. Size distributions of wear-originated metals resembled the pattern of crustal elements, which were predominated by super-micron particulates $\left(\mathrm{PM}_{1-10}\right)$. By contrast, tailpipe exhaust elements such as $\mathrm{Zn}, \mathrm{Pb}$, and $\mathrm{V}$ were distributed mainly in submicron particles. By employing $\mathrm{Cu}$ as a tracer of wear abrasion, several
\end{abstract}

inter-metal ratios - including $\mathrm{Fe} / \mathrm{Cu}(14), \mathrm{Ba} / \mathrm{Cu}$ (1.05), $\mathrm{Sb} / \mathrm{Cu}(0.16), \mathrm{Sn} / \mathrm{Cu}(0.10)$, and $\mathrm{Ga} / \mathrm{Cu}(0.03)$ - served as fingerprints for wear debris. However, the data set collected in this work is useful for further studies on traffic emission inventory and human health effects of traffic-related PM.

\section{Introduction}

Traffic emissions are an important source of particulate matter (PM) (Sternbeck et al., 2002; Birmili et al., 2006; Lough et al., 2005; Johansson et al., 2009) in the urban atmosphere. Exposure to traffic-derived PM poses adverse effects on human health and increases the risk of respiratory illness, cardiovascular diseases, and asthma (Brauer et al., 2002; Defino et al., 2005), resulting in increased mortality ( Nel, 2005). Airborne traffic-related PM is emitted mainly by tailpipe exhaust from gasoline and diesel engines (exhaust emissions), wear from brake linings and tires, and resuspension of road dust (non-exhaust emissions) by moving vehicles (Rogge et al., 1993; Cadle et al., 1999; Garg et al., 2000; Wåhlin et al., 2006; Lawrence et al., 2013). Exhaust emissions contribute a large amount of fine particulate matter (aerodynamic diameter less than $2.5 \mu \mathrm{m}, \mathrm{PM}_{2.5}$ ), whereas non-exhaust emissions mainly consist of larger particles (Abu-Allaban et al., 2002; 
Sanders et al., 2003). With regard to elemental compositions, $\mathrm{Pb}, \mathrm{Zn}, \mathrm{Ni}$, and $\mathrm{V}$ in submicron particles have commonly been attributed to pipe emissions and fuel oil combustion of both gasoline and diesel engines as shown in Table S1 in the Supplement (Lin et al., 2005; Wang et al., 2003; Shafer et al., 2012). Silicon ( $\mathrm{Si}$ ), $\mathrm{Fe}, \mathrm{Ca}, \mathrm{Na}, \mathrm{Mg}, \mathrm{Al}$, and $\mathrm{K}$ are essentially found in larger particles and are associated with resuspension of road dust. Large amounts of $\mathrm{Ca}$ and $\mathrm{K}$ observed in submicron particles occasionally originate from the tailpipe emission of lubricating oil as well as the vaporization of volatile $\mathrm{K}$ compounds and potassium titanate $\left(\mathrm{K}_{2} \mathrm{O} \cdot \mathrm{nTiO}_{2}\right)$, which is used for improving heat resistance and wear characteristics (Hee and Filip, 2005; Iijima et al., 2007; Kuo et al., 2009). Meanwhile, $\mathrm{Cu}, \mathrm{Ba}, \mathrm{Sb}, \mathrm{Fe}, \mathrm{Cd}, \mathrm{Cr}, \mathrm{Ga}, \mathrm{Sn}$, and $\mathrm{Zn}$, which are commonly associated with wear dust from brake linings and tires, are predominant in coarse PM (Lough et al., 2005; Grieshop et al., 2006; Thorpe and Harrison, 2008).

A number of studies have investigated the chemical and physical properties of traffic-originated PM by performing conventional dynamometric tests and field measurements near roads and inside tunnels (Sternbeck et al., 2002; Sanders et al., 2003; Birmili et al., 2006; Wåhlin et al., 2006; Iijima et al., 2007; Ning et al., 2007; Harrison et al., 2012; Dall'Osto et al., 2013; Lawrence et al., 2013). Dynamometric tests may allow optimal control of experimental conditions; however, the limitations of such tests are the costs and inadequate representative of real-world traffic emissions on the roads (Jamriska et al., 2004). A field measurement near the roadside is another method to well characterize the traffic-derived PM (Ning et al., 2008), but it may be influenced by local meteorological conditions and traffic activities (Jamriska et al., 2004; Ntziachristos et al., 2007). Accordingly, a tunnel study may be an alternative way to address this issue.

Tunnel aerosol sampling is designed to explore size distributions, chemical compositions, and emission factors of traffic-related aerosols and their associated compositions (Weingartner et al., 1997; Funasaka et al., 1998; Gillies et al., 2001; Sternbeck et al., 2002; Grieshop et al., 2006; Chiang and Huang, 2009; Pio et al., 2013). Pio et al. (2013) discriminated three main types of aerosols in Marquês Tunnel, Portugal, namely, carbonaceous, soil component, and vehicle mechanical wear. They also suggested that $\mathrm{Cu}$ is a good tracer for wear emissions of road traffic. Wear emission elements such as $\mathrm{Zn}, \mathrm{Sb}$, and $\mathrm{Ba}$ exhibited a peak mode in the size range of 3.2 to $5.6 \mu \mathrm{m}$. In comparison, $\mathrm{Pb}, \mathrm{Ca}$, and $\mathrm{Fe}$ partitioned within $0.1 \mu \mathrm{m}$ are mostly emitted from combustion of fuel and lubricant oil or vaporization from hot brake surfaces (Lough et al., 2005). Sternbeck et al. (2002) collected aerosol samples in two tunnels in Sweden and analyzed trace metals through inductively coupled plasma mass spectrometry (ICP-MS). They concluded that vehicle-related metals such as $\mathrm{Cu}, \mathrm{Zn}, \mathrm{Cd}, \mathrm{Sb}, \mathrm{Ba}$, and $\mathrm{Pb}$ - originated mainly from wear rather than from combustion, and that heavy-duty vehicles (HDVs), rather than light-duty vehicles (LDVs), are the leading emitter of $\mathrm{Ba}$ and $\mathrm{Sb}$. They further suggested that a
$\mathrm{Sb} / \mathrm{Cu}$ ratio of $\sim 0.22$ indicates the presence of brake wearrelated particles.

In this work, a series of aerosol sampling was conducted at two sites in Hsuehshan Tunnel by using microorifice uniform deposited impactors (MOUDIs) to characterize the physical and chemical properties of metallic aerosols under real driving conditions. In the past, several intensive measurements of aerosols have been carried out inside Hsuehshan Tunnel (Chang et al., 2009; Chen et al., 2010; Cheng et al., 2010a; Zhu et al., 2010); for instance, Zhu et al. (2010) characterized different temperature carbonaceous aerosols in fine PM and then identified their sources by the positive matrix factorization (PMF) approach. Moreover, number concentrations of ultrafine particles (UFPs) measured by Cheng et al. (2010a) indicate that UFPs, on average, were about $1.0 \times 10^{5}-3.0 \times 10^{5}$ particles $\mathrm{cm}^{-3}$, while higher UFP numbers were found at a traffic jam. They also suggested that gas-to-particle conversion is a crucial way to produce nucleation PM at the entrance of the tunnel, and coagulation growth of nucleation particles is an important mechanism for forming Aitken mode PM at the middle and exit section. Furthermore, gaseous pollutants - including VOC, $\mathrm{O}_{3}, \mathrm{CO}$, and $\mathrm{NO}_{x}$ - inside this tunnel have been also studied previously (Chang et al., 2009; Li et al., 2011, Lai and Peng, 2012). Thus, Hsuehshan Tunnel is a suitable study area for characterizing the behaviors of air pollutants associated with vehicle fleets. During the experimental campaigns, a total of 24 sets of size-resolved aerosol samples were collected; 36 target metals were analyzed by ICP-MS. Elemental compositions, size distributions, and fingerprinting metal ratios in traffic aerosols are reported in this paper. The resulting comprehensive data set would provide useful insight into health effect studies, source apportionment of atmospheric metals, and emissions inventory of traffic-related particulate metals.

\section{Methodology}

\subsection{Site description}

With a length of $12.9 \mathrm{~km}$, Hsuehshan Tunnel is the secondlongest road tunnel in Asia and the fifth longest in the world. Opened to traffic on June 2006, Hsuehshan Tunnel connects Pingling in New Taipei City and Toucheng in Yilan County. The tunnel has two separate two-lane bores and ascends steadily from $44 \mathrm{~m}$ a.m.s.l. (meters above mean sea level) at the south end (Toucheng) to $208 \mathrm{~m}$ a.m.s.l. at the north end (Pingling), that is, a slope of $1.26 \%$. Only passenger cars and light-duty trucks (which are both classified as LDVs) as well as shuttle buses (categorized as HDVs) are allowed to travel inside the tunnel, with vehicle speed limited to $90 \mathrm{~km} \mathrm{~h}^{-1}$. Four aerosol sampling campaigns were conducted in the northbound bore between May and September 2013; each campaign lasted for 3 days: Friday to Sunday. During the sampling period, the traffic volume passing 
Table 1. Summary of sampling dates; mass concentrations $\left(\mu \mathrm{g} \mathrm{m}^{-3}\right)$ of $\mathrm{PM}_{1.8-10}, \mathrm{PM}_{1-1.8}$, and $\mathrm{PM}_{1}$; traffic flow; and wind speed in Hsuehshan Tunnel during the sampling periods in 2013.

\begin{tabular}{|c|c|c|c|c|c|c|c|c|c|c|}
\hline \multirow{2}{*}{$\begin{array}{l}\text { Sampling } \\
\text { No. }\end{array}$} & \multirow[t]{2}{*}{ Date } & \multicolumn{3}{|c|}{ Inlet site } & \multicolumn{3}{|c|}{ Outlet site } & \multicolumn{2}{|c|}{ Vehicle fleet } & \multirow{2}{*}{$\begin{array}{l}\text { Wind } \\
\text { Speed } \\
\left(\mathrm{m} \mathrm{s}^{-1}\right)\end{array}$} \\
\hline & & $\mathrm{PM}_{1.8-10}$ & $\begin{array}{l}\mathrm{PM}_{1-1.8} \\
\left.\operatorname{lg~m}^{-3}\right)\end{array}$ & $\mathrm{PM}_{1}$ & $\mathrm{PM}_{1.8-10}$ & $\begin{array}{l}\mathrm{PM}_{1-1.8} \\
\left.\mathrm{~g} \mathrm{~m}^{-3}\right)\end{array}$ & $\mathrm{PM}_{1}$ & $\begin{array}{l}\text { LDV } \\
\left(\mathrm{No} \mathrm{h}^{-1}\right)\end{array}$ & $\begin{array}{l}\text { HDV } \\
\left(\text { No. }^{-1}\right)\end{array}$ & \\
\hline 1 & 17 May 2013 & 17 & 4 & 32 & 17 & 9 & 155 & 1272 & 72 & 4.7 \\
\hline 2 & 18 May 2013 & 18 & 7 & 43 & 18 & 11 & 128 & 1777 & 88 & 4.6 \\
\hline 3 & 19 May 2013 & 19 & 6 & 35 & 21 & 12 & 208 & 1843 & 109 & 4.7 \\
\hline 4 & 19 Jul 2013 & 16 & 4 & 27 & 26 & 9 & 83 & 1277 & 104 & 4.3 \\
\hline 5 & $20 \mathrm{Jul} 2013$ & 16 & 3 & 34 & 15 & 9 & 142 & 1400 & 118 & 4.8 \\
\hline 6 & $21 \mathrm{Jul} 2013$ & 13 & 3 & 33 & 20 & 9 & 168 & 1680 & 126 & 4.7 \\
\hline 7 & 8 Aug 2013 & 17 & 4 & 26 & 15 & 11 & 142 & 1354 & 109 & 4.7 \\
\hline 8 & 9 Aug 2013 & 19 & 4 & 39 & 9 & 10 & 87 & 1460 & 133 & 5.2 \\
\hline 9 & 10 Aug 2013 & 9 & 3 & 23 & 16 & 10 & 126 & 1712 & 81 & 4.9 \\
\hline 10 & 27 Sep 2013 & 27 & 4 & 22 & 28 & 10 & 125 & 1334 & 81 & 4.7 \\
\hline 11 & 28 Sep 2013 & 22 & 4 & 39 & 16 & 9 & 85 & 1764 & 101 & 5.0 \\
\hline 12 & 29 Sep 2013 & 15 & 4 & 34 & 18 & 10 & 180 & 1909 & 121 & 4.7 \\
\hline
\end{tabular}

through Hsuehshan Tunnel at the northbound, in general, approximated 1800 vehicles per hour on the weekend, which was 1.3 times higher than the workdays (see in Table 1). However, the traffic flow increased to 2300 vehicles $\mathrm{h}^{-1}$ from Sunday afternoon to evening, when people traveled back to Taipei; as a result, a traffic jam always occurred inside the tunnel beginning Sunday afternoon, probably influencing traffic-related PM metal emissions.

A ventilation system composed of three air exchange stations and three air interchange stations was built inside the tunnel to maintain air quality. Exchange and interchange stations are located alternatively at intervals of nearly $2 \mathrm{~km}$. In exchange stations, polluted air is exchanged with outer fresh air by using separate fresh and exhaust shafts equipped with two sets of fans. Fans are typically triggered at temperatures higher than $40^{\circ} \mathrm{C}$ or $\mathrm{CO}$ concentrations higher than $75 \mathrm{ppm}$. In interchange stations, the air in each bore is diverted into another bore by two sets of fans, which are also triggered when $\mathrm{CO}$ concentration exceeds $75 \mathrm{ppm}$. During the sampling periods, the ventilation system operated regularly, particular in July and August campaigns, when the air temperature near the outlet site is frequently more than $40^{\circ} \mathrm{C}$.

\subsection{Sampling and analysis}

During the sampling campaigns, two aerosol samplers were installed at 1.7 and $10.6 \mathrm{~km}$ from the entrance. The intakes of both aerosol instruments were placed $1.6 \mathrm{~m}$ above the pavement. MOUDIs (model 100, MSP Corporation, Minneapolis, Minnesota) equipped with pre-weighed Teflon filters (PTFE, $47 \mathrm{~mm}$ in diameter and $1.0 \mathrm{~mm}$ in pore size, Pall Gelman, East Hills, New York) were used to collect size-resolved aerosol samples. MOUDIs consist of 10 size-fractionating stages with $50 \%$ cut-off diameters of 10, 5.6, 3.2, 1.8, 1.0, $0.56,0.32,0.18,0.10$, and $0.056 \mu \mathrm{m}$, plus an inlet (nomi- nal cut size of $18 \mu \mathrm{m})$ and an after-filter $(<0.018 \mu \mathrm{m})$ at the base. Flow rate was calibrated prior to each sampling run and maintained at $30 \mathrm{~L} \mathrm{~min}^{-1}$. Each sample was collected for $12 \mathrm{~h}$ (typically from 09:00 to 21:00 local time, UTC + 8) daily.

After sampling, filter samples were conditioned for $48 \mathrm{~h}$, followed by gravimetric measurement at $23^{\circ} \mathrm{C}$ and $\mathrm{RH}$ of $30 \pm 5 \%$ with a microbalance (METTLER TOLEDO, MX5, AX205, precision $1 \mu \mathrm{g}$ ) to determine the net mass of collected aerosol particles, which is needed to calculate the PM mass concentration. The samples were then subjected to acid digestion with the use of an ultra-high-throughput microwave digestion system (MARSXpress, CEM Corporation, Matthews, NC, USA). The vessels were acid-cleaned thoroughly prior to sample digestion. A half of each sample filter was digested in an acid mixture $\left(1.5 \mathrm{~mL}\right.$ of $60 \% \mathrm{HNO}_{3}$ and $1.5 \mathrm{~mL}$ of $48 \% \mathrm{HF})$. After digestion, the vessels were transferred to the XpressVap ${ }^{\mathrm{TM}}$ accessory sets (CEM) for evaporation of the remaining acids. When nearly dried, $2 \mathrm{~mL}$ of concentrated $\mathrm{HNO}_{3}$ was added into each vessel and reheated. The resulting solution was then diluted with Milli-Q water to a final volume of $15 \mathrm{~mL}$ for analysis. The digestion procedure has been detailed in previous studies (Hsu et al., 2008, 2009; Zhang et al., 2013).

A total of 36 target elements in aerosols were analyzed by ICP-MS (Elan 6100, Perkin ElmerTM SCIEX, USA). For each run, a blank reagent and three filter membrane blanks were subjected to the same procedure as that for the samples. Indium (In) was added to the digestion as an internal standard with a final concentration of $10 \mathrm{ng} \mathrm{mL}^{-1}$ for ICP-MS analysis. The QA/QC of data is guaranteed by the analysis of a standard reference material, SRM 1648 (urban atmospheric particulate matter prepared by the National Institute of Standards and Technology, NIST). The recoveries of target ele- 
ments mostly fell within $10 \%(n=7)$ of certified or reference values (Table S2). The method detection limits (MDLs) for the analyzed elements are also presented. Details of the ICP-MS analysis have been extensively discussed by Hsu et al. (2010) and Zhang et al. (2013).

\subsection{Enrichment factor and principal component analysis}

In addition to size distribution, three approaches - namely, enrichment factor $(\mathrm{EF})$, correlation matrix, and principal component analysis (PCA) - were applied to explore the possible sources and associations of elements. EF is used to assess the influence of crustal source on a given metal (Xi), which can be calculated by using the following equation:

$\mathrm{EF}(\mathrm{Xi})=\frac{\left(X_{i} / \mathrm{Al}\right)_{\mathrm{PM}}}{\left(X_{i} / \mathrm{Al}\right)_{\text {Crust }}}$,

where $\left(X_{i} / \mathrm{Al}\right)_{\mathrm{PM}}$ is the concentration ratio of a given element $X$ to $\mathrm{Al}$ in tunnel particulate matters and $\left(X_{i} / \mathrm{Al}\right)_{\text {crust }}$ is the concentration ratio of an interested element $X$ to $\mathrm{Al}$ in the average crustal abundance (Taylor, 1964).

PCA can elucidate variance in a given data set in terms of minimum number of significant components. This technique has been employed in the tunnel studies concerning source apportionment of airborne metals (Lin et al., 2005; Lawrence et al., 2013). The software used here is STATISTICA 12 (Statsoft Inc.). A factor loading of $>0.7$ was adopted in this study to assign source identification to a given principal component.

\section{Result and discussions}

\subsection{Chemical compositions}

Table 1 summarizes the data on PM mass concentrations in size-resolved aerosols at both the inlet and outlet sites in Hsuehshan Tunnel. The aerosols are treated into three size bins: submicron $\left(\mathrm{PM}_{1}\right)$, fine $\left(\mathrm{PM}_{1-1.8}\right)$, and coarse ( $\left.\mathrm{PM}_{1.8-10}\right)$ modes. During the sampling periods, the mass concentrations of $\mathrm{PM}_{10}$, which were determined as the sum of aerosol masses at all corresponding stages with a cutoff diameter less than $10 \mu \mathrm{m}$, ranged from 35 to $68 \mu \mathrm{g} \mathrm{m}^{-3}$ (average: $54 \pm 9 \mu \mathrm{g} \mathrm{m}^{-3}$ ) at the inlet site and from 106 to $241 \mu \mathrm{g} \mathrm{m}^{-3}$ (average: $162 \pm 42 \mu \mathrm{g} \mathrm{m}^{-3}$ ) at the outlet site. Submicron particles were the predominant fraction, accounting for $60 \pm 6$ and $82 \pm 3 \%$ of $\mathrm{PM}_{10}$ mass at the entrance and the exit, respectively. The abundance of submicron PM may indicate that combustion processes are significant sources of tunnel aerosols, which are presumably dominated by carbonaceous particles (Zhu et al., 2010; Pio et al., 2013). Compared with the inlet site, higher concentrations of $\mathrm{PM}_{1-1.8}$ and $\mathrm{PM}_{1}$ were observed at the outlet site by a factor of 2.5 and 4.4, respectively. For $\mathrm{PM}_{1.8-10}$, the concentration at the outlet site was nearly equal to that at the inlet site (outlet-toinlet ratio: 1.1). The outlet-to-inlet ratio of PM mass concentration increases with decreasing PM size, indicating that smaller particles are relatively efficiently transported from the entrance to the exit; previous studies have attributed such efficient transport to the "piston effect" (Chang et al., 2009; Cheng et al., 2010a; Moreno et al., 2014). These authors suggested that passing vehicles pick up air pollutants emitted from vehicle fleets and the flows lead them to the exit, resulting in the accumulation of large quantities of air pollutants in that area. On the other hand, the discrepancies of out-to-inlet ratios in $\mathrm{PM}_{1.8-10}, \mathrm{PM}_{1-1.8}$, and $\mathrm{PM}_{1}$ could also be ascribed to the distinct emission rates for PM in different size fractions inside the tunnel.

Figure 1a shows the average elemental concentrations of $\mathrm{PM}_{10}$ at the two sites in Hsuehshan Tunnel, and Fig. 1b depicts the partitioning of trace elements among three size bins. As shown in Fig. 1a, Fe was the most abundant element, with a mean concentration of $2384 \pm 1416 \mathrm{ng} \mathrm{m}^{-3}$. In addition to $\mathrm{Na}, \mathrm{Ca}$, and $\mathrm{Al}$ (300 to $500 \mathrm{ng} \mathrm{m}^{-3}$ ), $\mathrm{Zn}, \mathrm{K}$, $\mathrm{Ba}, \mathrm{Cu}$, and $\mathrm{Mg}$ (up to $100 \mathrm{ng} \mathrm{m}^{-3}$ ) were also major metals in $\mathrm{PM}_{10}$, followed by Ti $\left(73 \mathrm{ng} \mathrm{m}^{-3}\right)$, Mn $\left(29 \mathrm{ng} \mathrm{m}^{-3}\right)$, and $\mathrm{Sb}\left(23 \mathrm{ng} \mathrm{m}^{-3}\right)$, and then followed by $\mathrm{Mo}, \mathrm{Pb}, \mathrm{Ga}, \mathrm{Sr}$, $\mathrm{Ni}, \mathrm{V}$, and $\mathrm{Ce}\left(1\right.$ to $\left.10 \mathrm{ng} \mathrm{m}^{-3}\right)$. The rest of the elements have concentrations less than $1 \mathrm{ng} \mathrm{m}^{-3}$ (i.e., $0.9 \mathrm{ng} \mathrm{m}^{-3}$ for Bi to $0.02 \mathrm{ng} \mathrm{m}^{-3}$ for U). Most elements exhibited significantly higher concentrations at the exit than at the entrance ( $p<0.05$, Fig. 1c), with the exception of a number of crustal elements such as $\mathrm{Al}, \mathrm{K}, \mathrm{Mg}$, and $\mathrm{Rb}$. This suggests that a lower road dust reservoir is present inside the freeway tunnel (Amato et al., 2012). Considerably high outlet-to-inlet ratios (ranging from 2.2 for $\mathrm{Sr}$ to 4.3 for $\mathrm{Zn}$ ) were found for trafficderived elements, including $\mathrm{Zn}, \mathrm{Cu}, \mathrm{Ba}, \mathrm{Mn}, \mathrm{Sb}, \mathrm{Sn}, \mathrm{Pb}, \mathrm{Ga}$, $\mathrm{Sr}$, and $\mathrm{Cd}$.

\subsection{Size distributions}

The average size distributions of some of the analyzed metals are shown in Figs. 1b, 2, and S1. Barium (Ba), Cd, Cu, $\mathrm{Fe}, \mathrm{Ga}, \mathrm{Mn}, \mathrm{Mo}, \mathrm{Sb}$, and $\mathrm{Sn}$ were predominant in coarse mode at the inlet site (Fig. 1b). These elements displayed a typical mono-modal distribution with a major peak in the size range of 3.2-5.6 $\mu \mathrm{m}$, while they had another small peak at $1.0-1.8 \mu \mathrm{m}$ at times (Figs. 2 and S2). The size distribution patterns of these metals were consistent with the results observed by Harrison et al. (2012) at a curbside in central London. The authors assigned the elements $\mathrm{Fe}, \mathrm{Cu}, \mathrm{Sb}, \mathrm{Ba}$, and $\mathrm{Zn}$ to the non-exhaust traffic particles. At the outlet site, those elements (Ba, Cd, Cu, Fe, Ga, Mn, Mo, Sb, and $\mathrm{Sn}$ ) similarly had a mono-modal size distribution, but the main peak shifted to $1.0-1.8 \mu \mathrm{m}$ (Figs. 2 and S2). Similar to that in PM mass, this shift was perhaps due to the piston effect, which, as previously mentioned, facilitated the transport of finer PM to the exit. 

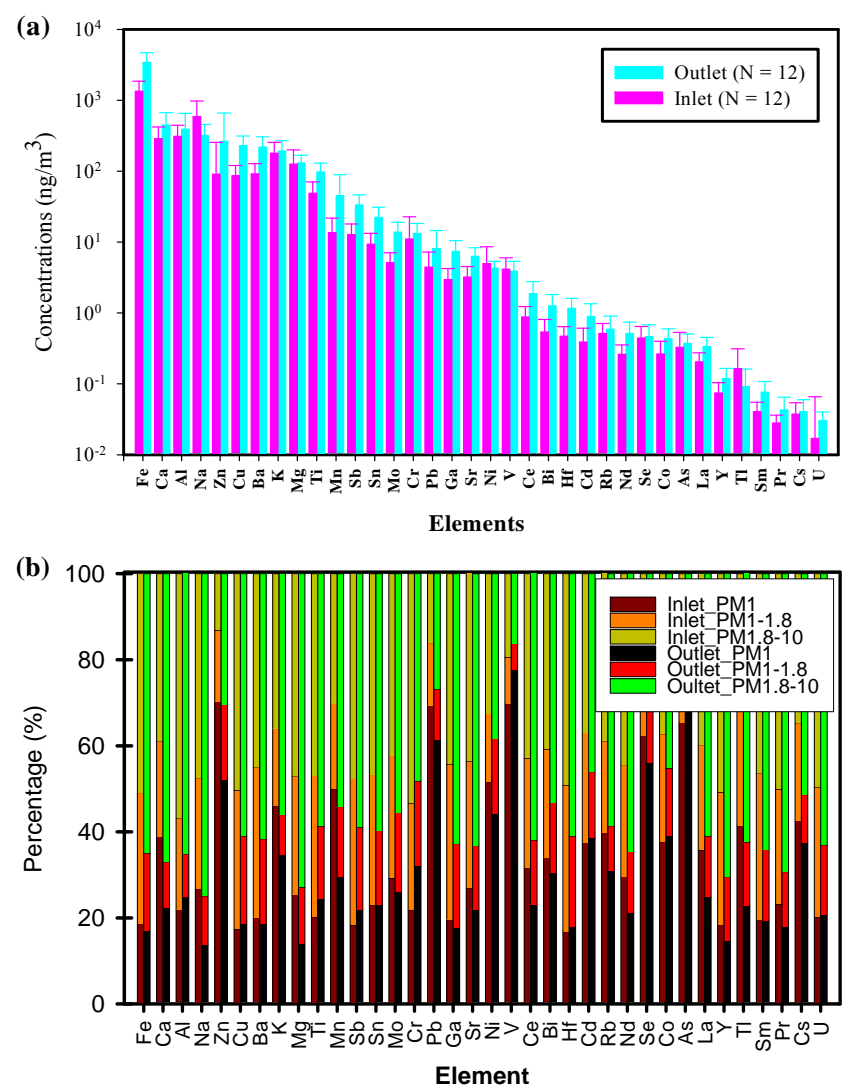

(c)

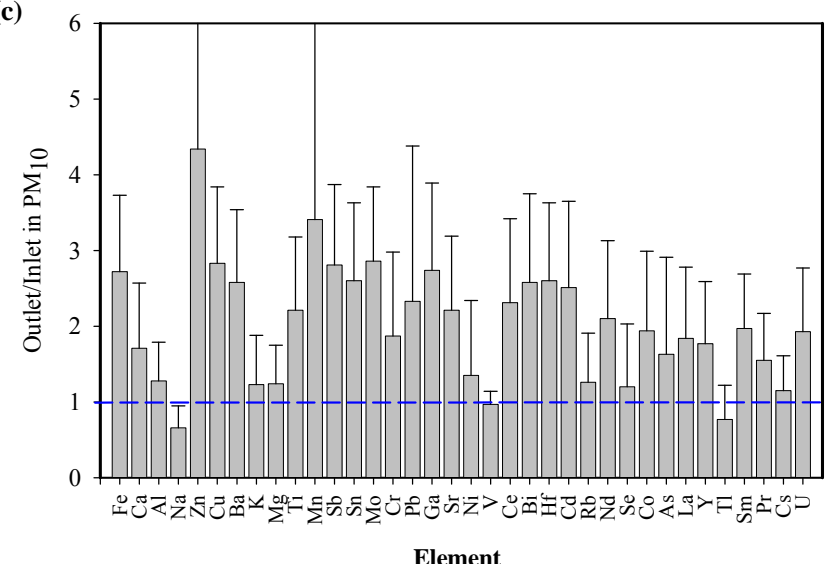

Figure 1. (a) Elemental compositions of $\mathrm{PM}_{10}$ collected at both the inlet and outlet sites in Hsuehshan Tunnel; (b) partitioning of trace metals within PM of three sizes; (c) outlet-to-inlet ratio for each element in $\mathrm{PM}_{10}$. The sequence of metallic species is in order of decreasing concentrations $\left(\mathrm{ng} \mathrm{m}^{-3}\right)$ at the outlet site. $N$ denotes the number of aerosol samples.

Zinc (Zn) showed a bimodal distribution for most samples at the entrance, with a major peak in the size range of 3.2$5.6 \mu \mathrm{m}$ and a second peak in the size range of $0.56-1.0 \mu \mathrm{m}$. Meanwhile, a mono-modal pattern with a major peak at 1.0 $1.8 \mu \mathrm{m}$ was found at the exit. Lead $(\mathrm{Pb})$ displayed two peaks at the inlet site: one at $0.56-1.0 \mu \mathrm{m}$ and another one at $3.2-$
$5.6 \mu \mathrm{m}$. However, $\mathrm{Pb}$ exhibited a typical mono-modal distribution at the outlet site, peaking at $0.32-0.56 \mu \mathrm{m}$. Vanadium (V) revealed a bimodal size pattern with a major peak at $0.32-0.56 \mu \mathrm{m}$ and a second peak at $3.2-5.6 \mu \mathrm{m}$ at the inlet site, whereas it peaked at $0.18-0.32$ or $0.32-0.56 \mu \mathrm{m}$ at the exit.

Aluminum (Al), $\mathrm{Ca}$, and $\mathrm{Mg}$ of predominant geological origins showed a typical mono-modal size distribution at the inlet site with a major peak at 3.2-5.6 $\mu \mathrm{m}$; however, a peak was occasionally found in the submicron particles (Figs. S1 and S3). For example, the abundance of $\mathrm{Al}, \mathrm{Ca}$, and $\mathrm{K}$ was observed at submicron size in two sets of samples (21 July and 10 August). This abundance was ascribed to non-crustal sources such as vaporization from lubricating oil and diesel emissions (Wang et al., 2003), which perhaps alters the size distributions of these crustal elements. Submicron mode, which is an indicator of combustion or high-temperature processes, contributes non-negligible $\mathrm{Ca}$ and $\mathrm{K}$, which are usually regarded as crustal elements. Potassium titanate and a number of volatile compounds are known to contain $\mathrm{K}$ and therefore may be the sources of submicron K (Hee and Filip, 2005; Iijima et al., 2007). Submicron Ca probably originated from tailpipe emissions of lubricating oil (Kuo et al., 2009). Like traffic elements, these crustal elements had a major peak that shifted to $1.0-1.8 \mu \mathrm{m}$ at the outlet site, which also arose from the piston effect. At the inlet site, rare earth elements (REEs) - such as $\mathrm{La}, \mathrm{Ce}, \mathrm{Nd}, \mathrm{Pr}$, and $\mathrm{Sm}$ - revealed a monomodal size distribution with a major peak at 3.2-5.6 $\mu \mathrm{m}$. At the exit, these elements essentially showed a mono-modal distribution that peaked at 1.0-1.8 $\mu \mathrm{m}$ (Fig. S3).

\subsection{Sources of trace metals}

Figure 3 presents the results of enrichment factor analysis for all analyzed elements in three size bins of size-segregated particles at both the inlet and outlet sites. EF values for all species were higher at the outlet than at the inlet site, suggesting that the influence of resuspended road dust was insignificant for most metals at the exit. Enrichment factor values for $\mathrm{Ca}, \mathrm{K}, \mathrm{Mg}, \mathrm{Rb}, \mathrm{Sr}$, and $\mathrm{Ti}$ in the three size-resolved particles were generally close to unity at both sites, demonstrating that these elements originated mainly from the resuspension of soil and road dust. EF values for these geological metals increased with decreasing size, indicating that these elements in smaller particles would be significantly influenced by anthropogenic sources such as diesel emissions, lubricating oil, and additives in oil fuels. For lanthanides, lower enrichment was found for $\mathrm{La}, \mathrm{Pr}, \mathrm{Nd}$, and $\mathrm{Sm}$ in all three sizes of PM, although high EFs were occasionally found. This indicates that, although such elements mainly originate from geological sources, they are sometimes from mixed sources of dust and anthropogenic emissions such as automotive catalysts (Kulkarni et al., 2006). Cerium (Ce), which is one of the lanthanides, had higher EF values (>10) in all sizeresolved particles than $\mathrm{La}, \mathrm{Pr}, \mathrm{Nd}$, and $\mathrm{Sm}$, demonstrating 

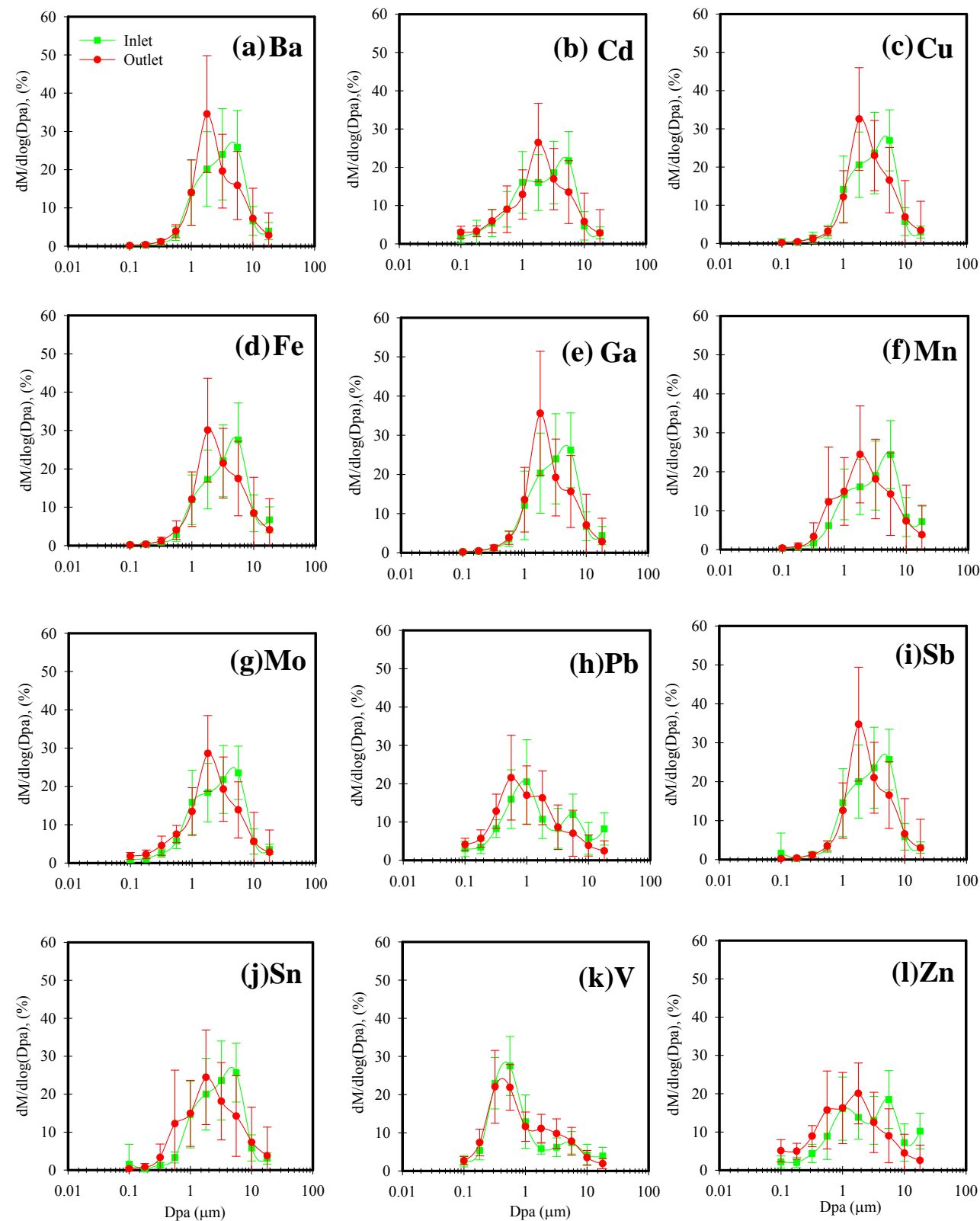

Figure 2. Average size distributions of traffic-derived elements observed at the inlet and outlet sites inside Hsuehshan Tunnel.

that $\mathrm{Ce}$ is highly influenced by anthropogenic emissions. For the three size-resolved particles, Ce is highly correlated not only with $\mathrm{La}, \mathrm{Pr}, \mathrm{Nd}$, and $\mathrm{Sm}$ but also with a number of anthropogenic elements, again implying that Ce originated from traffic emissions such as automotive catalysts and fuel additives of diesel vehicles as well as from a crustal source (Kulkarni et al., 2006; Cassee et al., 2011).

High EFs (> 10) were obtained for As, $\mathrm{Ba}, \mathrm{Cd}, \mathrm{Cu}, \mathrm{Cr}, \mathrm{Ga}$, $\mathrm{Mo}, \mathrm{Sb}, \mathrm{Se}$, and $\mathrm{Sn}$, indicating their anthropogenic origins. Among these elements, $\mathrm{Cu}$ is an additive in high-temperature lubricant and is present in brake linings, approximately 1$10 \%$ by weight (Sanders et al., 2003), and it has been used successfully as a good tracer for wear emission of road traffic (Pio et al., 2013). Correlation analyses (Table 2) illustrate that $\mathrm{Ba}, \mathrm{Cd}, \mathrm{Ga}, \mathrm{Mo}, \mathrm{Sb}$, and $\mathrm{Sn}$ are well correlated with $\mathrm{Cu}(r>0.93)$ in both coarse and fine modes, suggesting that, similar to $\mathrm{Cu}$, these elements in Hsuehshan Tunnel originated mainly from wear-abrasive sources. This could be supported by the presence of both $\mathrm{BaSO}_{4}$ - and $\mathrm{Sb}_{2} \mathrm{~S}_{3}$-containing particles in both brake lining materials, in which the former is utilized as a filler and the latter is utilized as an alternative to asbestos (Ingo et al., 2004). Moreover, the use of organic $\mathrm{Sb}$ compounds in grease and motor oil is another road traffic emission source of Sb (Huang et al., 1994; Cal-Prieto, 2001). 


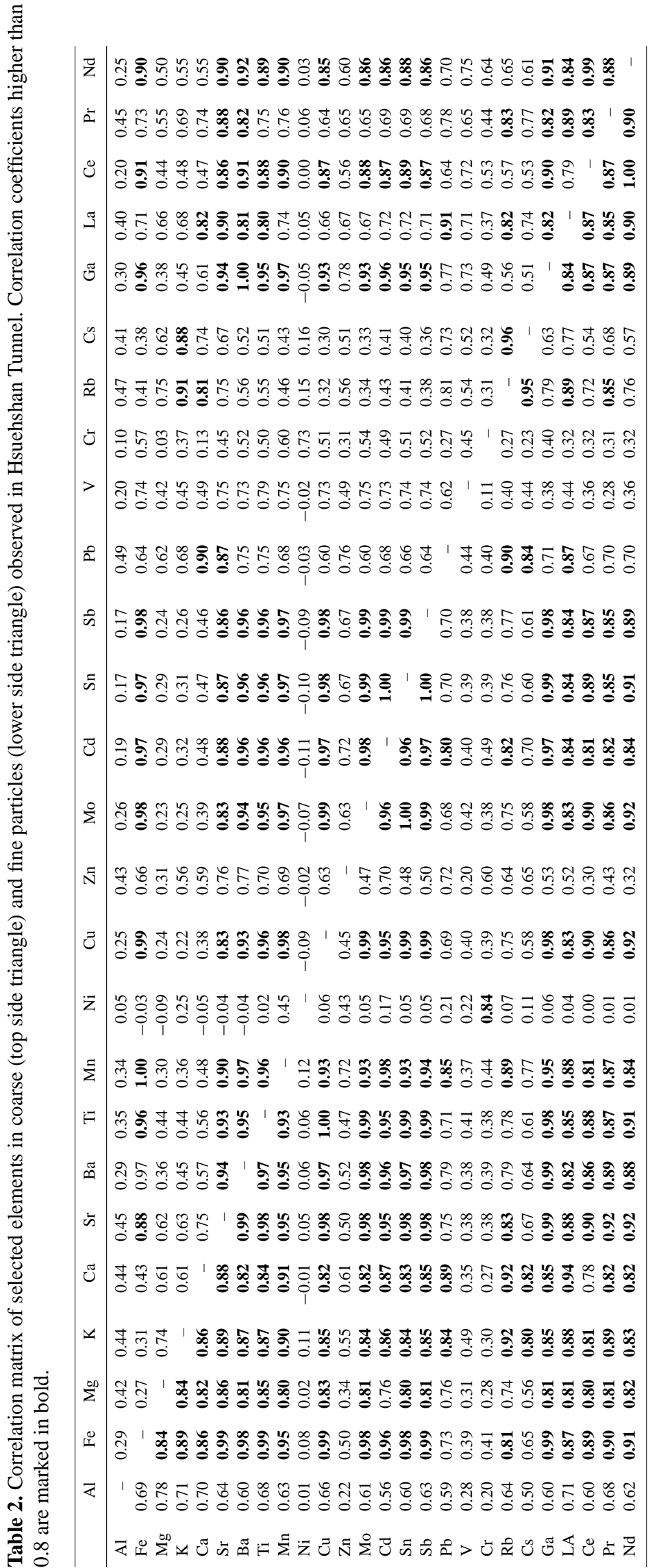




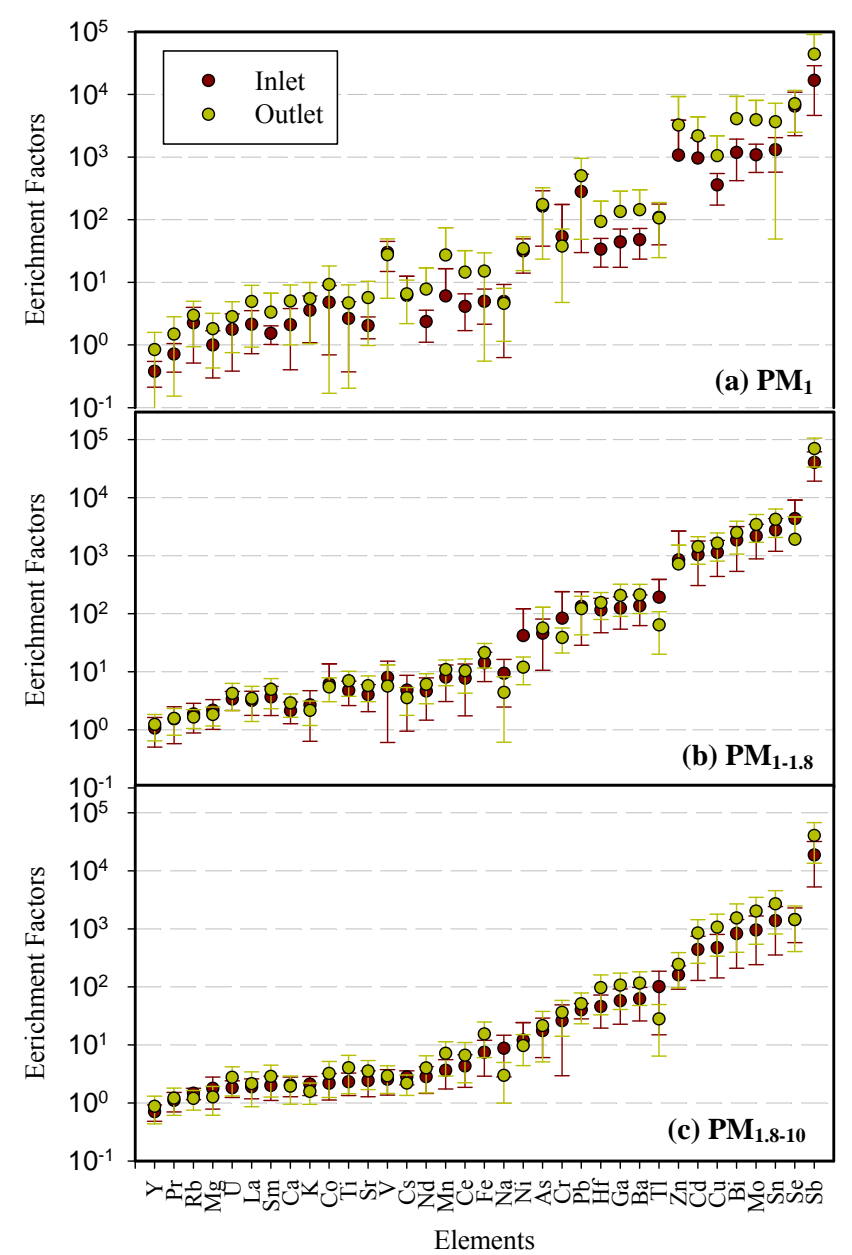

Figure 3. Enrichment factors of trace metals in (a) $\mathrm{PM}_{1}$, (b) $\mathrm{PM}_{1-1.8}$ and (c) $\mathrm{PM}_{1.8-10}$ observed at the inlet and outlet sites in Hsuehshan Tunnel.

Lead $(\mathrm{Pb})$ and $\mathrm{Zn}$ show high enrichment in all size fractions, indicating that both elements are contributed primarily by traffic emissions, rather than a natural origin. According to the bimodal distribution (Fig. 2) and the good correlations with $\mathrm{Cu}, \mathrm{Ba}$, and $\mathrm{Sb}(r>0.63)$ in $\mathrm{PM}_{1.8-10}$ (Table 2), $\mathrm{Zn}$ appears to originate from traffic emissions, and two traffic sources could account for the observed $\mathrm{Zn}$. For the coarse mode, $\mathrm{Zn}$ is associated with wear tire debris because $\mathrm{Zn}$ is added to tires during vulcanization and is responsible for $1-2 \%$ of the tires by weight (Degaffe and Turner, 2011; Taheri et al., 2011). This is in concert with previous results (Adachi and Tainosho, 2004; Councell et al., 2004; Tanner et al., 2008; Harrison et al., 2012). For the fine mode, $\mathrm{Zn}$ is probably contributed by lubrication oil via pipe emissions (Huang et al., 1994). Emissions from vehicle exhaust and wear abrasion are both important sources of $\mathrm{Pb}$. In this work, $\mathrm{Pb}$ showed a good correlation with $\mathrm{Cu}, \mathrm{Sb}, \mathrm{Ba}$, and $\mathrm{Zn}(r>0.60)$ in coarse PM, indicating wear debris origins. In fine mode, $\mathrm{Pb}$ correlated well with $\mathrm{Cu}, \mathrm{Sb}$, and $\mathrm{Ba}(r>0.69)$, suggesting wear abrasion dust. Moreover, a good correlation between $\mathrm{Pb}$ and $\mathrm{Zn}(r=0.75$, in Table 2) was also found, revealing that $\mathrm{Pb}$ in fine $\mathrm{PM}$ might also be derived from diesel engines since both species were detected together and constituted up to $2 \%$ in fresh diesel PM (Sharma et al., 2005; Agarwal et al., 2015). However, $\mathrm{Pb}$ only correlated well with $\mathrm{Zn}(r=0.77)$ in submicron size (in Table S3), reflecting that $\mathrm{Pb}$ was preferentially contributed by the combustion process from vehicle fleets (Wang et al., 2003).

Iron $(\mathrm{Fe})$, which is considered an important crustal element, exhibited enrichment factors of 5 to 11 at the entrance and 12 to 21 at the exit, indicating that Fe in the tunnel was mainly produced from anthropogenic emissions other than road dust. Previous studies have pointed out that, in addition to road dust, wear debris from brake linings and tires as well as diesel engine emissions are main sources of $\mathrm{Fe}$ in areas near traffic emissions (Cadle et al., 1997; Garg et al., 2000; Wang et al., 2003). In the present study, Fe correlated well with $\mathrm{Cu}, \mathrm{Ba}$, and $\mathrm{Sb}$ in all sizes $(r>0.87$, Tables 2 and $\mathrm{S} 3$ ), demonstrating that wear dust is a major anthropogenic source of Fe in Hsuehshan Tunnel, as is the case for those elements.

PCA results are presented in Table 3, in which the data (samples) are divided into three size groups. Two possible sources are identified for coarse PM. As seen, PC1 was associated with $\mathrm{Fe}, \mathrm{Ba}, \mathrm{Mn}, \mathrm{Cu}, \mathrm{Mo}, \mathrm{Cd}, \mathrm{Sb}, \mathrm{Ti}, \mathrm{V}$, and $\mathrm{Ga}$; moderate loadings were found for $\mathrm{Zn}$ and $\mathrm{Pb}$. This indicates that PC1 was likely attributed to wear debris (Wåhlin et al., 2006; Lawrence et al., 2013; Pio et al., 2013). In PC2, high loadings were found for $\mathrm{Na}, \mathrm{Mg}, \mathrm{K}, \mathrm{Ca}$, and $\mathrm{Rb}$, implying road dust origins. For fine particles, $\mathrm{Fe}, \mathrm{Ba}, \mathrm{Mn}, \mathrm{Cu}, \mathrm{Mo}, \mathrm{Cd}$, $\mathrm{Sb}, \mathrm{Mg}, \mathrm{K}, \mathrm{Ca}, \mathrm{Rb}, \mathrm{La}$, and $\mathrm{Ce}$ had high loadings, whereas $\mathrm{Pb}$ had moderate loadings in $\mathrm{PC} 1$; brake abrasion mixed with resuspended dust and gasoline emissions might explain this factor. In PC2, high positive loading was found for $\mathrm{Zn}$ and moderate loading for $\mathrm{Pb}$; thus, $\mathrm{PC} 2$ could be explained by diesel emissions (Sharma et al., 2005; Agarwal et al., 2015). The third component was identified as road dust because of the correlations among $\mathrm{Na}, \mathrm{Al}$, and $\mathrm{Mg}$ (loadings > 0.6). For submicron particles, high loadings were found for $\mathrm{Fe}, \mathrm{Ba}$, $\mathrm{Cu}, \mathrm{Mo}, \mathrm{Sb}, \mathrm{Ga}$, and $\mathrm{Ce}$ in $\mathrm{PC} 1$. As previously mentioned, $\mathrm{Ce}$ in smaller PM may be associated with catalytic converters and fuel additives; therefore, PC1 might be grouped into mixed sources of wear abrasion and automotive catalysts. In $\mathrm{PC}$, high positive loadings were found for $\mathrm{Pb}$ and $\mathrm{Zn}$, illustrating that exhaust from diesel engine was a potential source in this component. However, PC3, which had a high loading of $\mathrm{Al}$ and a moderate loading of $\mathrm{Ca}$, indicates that road dust could be the potential source. PC4 is a component with high loading for $\mathrm{V}$ and $\mathrm{Ni}$. Previous studies have suggested that $\mathrm{V}$ and $\mathrm{Ni}$ in submicron particles were commonly attributed to fuel oil combustion of gasoline and diesel engines (Wang et al., 2003; Shafer et al., 2012), but higher emission rates for gasoline exhaust compared to diesel engines (Cheng et al., 2010b). Consequently, PC4 in submicron PM may be associated preferentially to gasoline engines. Overall, wear abra- 
Table 3. Summaries of principal component analysis for trace metals in coarse, fine and submicron particles observed in Hsuehshan Tunnel. Factor loadings lower than \pm 0.4 are not given. Factor loadings greater than 0.7 are marked in bold.

\begin{tabular}{|c|c|c|c|c|c|c|c|c|c|}
\hline & \multicolumn{2}{|c|}{ Coarse } & \multicolumn{3}{|c|}{ Fine } & \multicolumn{4}{|c|}{ Submicron } \\
\hline & PC1 & PC2 & $\mathrm{PC} 1$ & $\mathrm{PC} 2$ & PC3 & PC1 & PC2 & PC3 & $\mathrm{PC} 4$ \\
\hline $\mathrm{Al}$ & & 0.55 & 0.52 & - & 0.68 & - & - & 0.88 & - \\
\hline $\mathrm{Fe}$ & 0.98 & - & 0.94 & - & - & 0.82 & 0.52 & - & - \\
\hline $\mathrm{Na}$ & - & 0.81 & - & - & 0.93 & - & - & - & - \\
\hline $\mathrm{Mg}$ & - & 0.89 & 0.70 & - & 0.66 & 0.69 & - & - & - \\
\hline $\mathrm{K}$ & - & 0.88 & 0.77 & - & 0.44 & - & 0.57 & - & - \\
\hline $\mathrm{Ca}$ & - & 0.75 & 0.81 & - & - & 0.65 & - & 0.53 & - \\
\hline $\mathrm{Ba}$ & 0.94 & - & 0.95 & - & - & 0.96 & - & - & - \\
\hline $\mathrm{Ti}$ & 0.93 & - & 0.94 & - & - & 0.73 & - & - & - \\
\hline $\mathrm{Mn}$ & 0.97 & - & 0.90 & - & - & - & 0.96 & - & - \\
\hline $\mathrm{Ni}$ & - & - & - & 0.76 & - & - & - & 0.56 & 0.72 \\
\hline $\mathrm{Cu}$ & 0.98 & - & 0.95 & - & - & 0.96 & - & - & - \\
\hline $\mathrm{Zn}$ & 0.65 & 0.42 & 0.44 & 0.79 & - & - & 0.97 & - & - \\
\hline Mo & 0.99 & - & 0.96 & - & - & 0.96 & - & - & - \\
\hline $\mathrm{Cd}$ & 0.97 & - & 0.92 & - & - & - & 0.90 & - & - \\
\hline $\mathrm{Sb}$ & 0.99 & - & 0.96 & - & - & 0.90 & - & - & - \\
\hline $\mathrm{Pb}$ & 0.58 & 0.71 & 0.62 & 0.61 & - & - & 0.84 & - & - \\
\hline V & 0.72 & - & - & - & - & - & - & - & 0.92 \\
\hline $\mathrm{Rb}$ & - & 0.90 & 0.73 & 0.44 & - & - & 0.63 & - & - \\
\hline $\mathrm{Ga}$ & 0.93 & - & 0.96 & - & - & 0.94 & - & - & - \\
\hline $\mathrm{La}$ & 0.65 & 0.68 & 0.80 & - & - & 0.81 & - & - & - \\
\hline $\mathrm{Ce}$ & 0.86 & - & 0.86 & - & - & 0.92 & - & - & - \\
\hline $\begin{array}{l}\text { Potential } \\
\text { source }\end{array}$ & $\begin{array}{l}\text { Wear } \\
\text { debris }\end{array}$ & Dust & $\begin{array}{l}\text { Wear debris }+ \\
\text { dust }+ \text { gasoline }\end{array}$ & Diesel & Dust & $\begin{array}{l}\text { Wear debris }+ \\
\text { auto catalyst }\end{array}$ & Diesel & Dust & $\begin{array}{l}\text { Fuel } \\
\text { oil }\end{array}$ \\
\hline
\end{tabular}

Table 4. Ratios of specific elements to $\mathrm{Cu}$ in tunnel PM.

\begin{tabular}{|c|c|c|c|c|c|c|}
\hline Tunnel studies & Size & $\mathrm{Fe} / \mathrm{Cu}$ & $\mathrm{Ba} / \mathrm{Cu}$ & $\mathrm{Sb} / \mathrm{Cu}$ & $\mathrm{Sn} / \mathrm{Cu}$ & Reference $^{b}$ \\
\hline Hatfield Tunnel (United Kingdom) & $\mathrm{PM}_{10}$ & 19 & 1.23 & 0.13 & - & 1 \\
\hline Marquês de Pombal Tunnel (Portugal) & $\mathrm{PM}_{0.5-10}$ & 16 & 0.27 & 0.08 & 0.23 & 2 \\
\hline Tingstad Tunnel (Sweden) & $\mathrm{PM}_{10}$ & 28 & 0.74 & 0.18 & - & 3 \\
\hline Lundby Tunnel (Sweden) & $\mathrm{PM}_{10}$ & 60 & 1.34 & 0.24 & - & 3 \\
\hline Malraux Tunnel (France) & $\mathrm{PM}_{2.5}$ & 15 & - & 0.14 & 0.14 & 4 \\
\hline Squirrel Hill Tunnel (USA) ${ }^{\mathrm{a}}$ & $\mathrm{PM}_{2.5}$ & 37 & 2.48 & 0.21 & 0.48 & 5 \\
\hline Sepulveda Tunnel (USA) ${ }^{\mathrm{a}}$ & $\mathrm{PM}_{2.5}$ & 16 & 2.12 & 0.88 & 0.82 & 6 \\
\hline Loma Largo Tunnel (Mexico) & $\mathrm{PM}_{2.5}$ & 7 & 0.13 & 0.76 & 0.49 & 7 \\
\hline Jãnio Tunnel (Brazil) & $\mathrm{PM}_{2.5}$ & 20 & - & 0.12 & - & 8 \\
\hline Belway Rodonael Mário Covas Tunnel (Brazil) & $\mathrm{PM}_{2.5}$ & 45 & - & 0.36 & - & 8 \\
\hline Shing Mun Tunnel (Hong Kong) & $\mathrm{PM}_{2.5}$ & 17 & 0.58 & 0.14 & 0.29 & 9 \\
\hline \multirow[t]{2}{*}{ Zhujiang Tunnel (China) } & $\mathrm{PM}_{2.5}$ & 28 & 1.08 & - & - & 10 \\
\hline & $\mathrm{PM}_{1.8-10}$ & 14 & 0.80 & 0.14 & 0.09 & \\
\hline \multirow[t]{2}{*}{ Hsuehshan Tunnel (Taiwan) } & $\mathrm{PM}_{1-1.8}$ & 14 & 1.07 & 0.16 & 0.09 & This study \\
\hline & $\mathrm{PM}_{1}$ & 15 & 1.10 & 0.16 & 0.11 & \\
\hline
\end{tabular}

${ }^{a}$ The ratios of Squirrel Hill Tunnel and Sepulveda Tunnel are obtained from the ratios of elemental emission factors. ${ }^{b} 1$. Lawrence et al. (2013); 2. Pio et al. (2013); 3. Sternbeck et al. (2002); 4. Fabretti et al. (2009); 5. Grieshop et al. (2006); 6. Gillies et al. (2001); 7. Mancilla and Mendoza (2012); 8. Brito et al. (2013); 9. Cheng et al. (2010b); 10. He et al. (2008). 

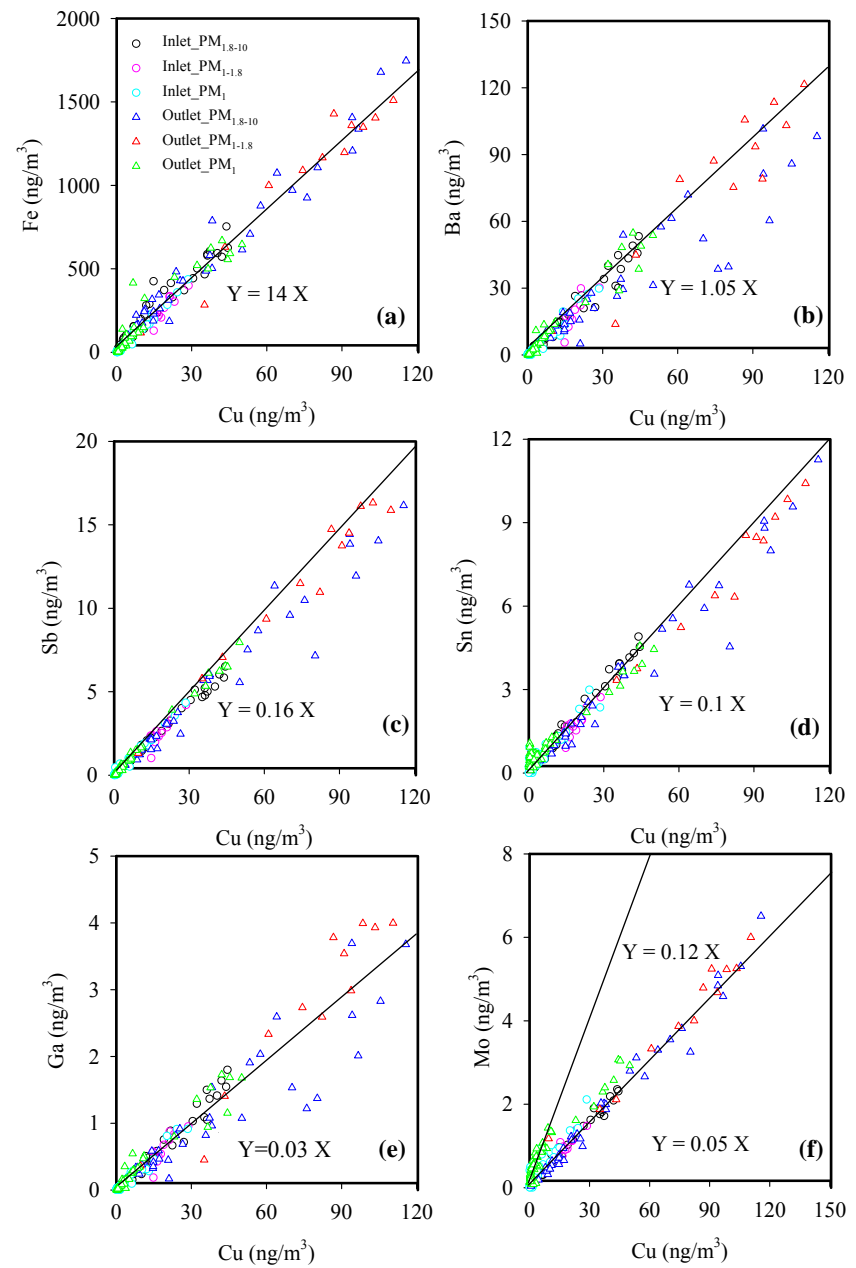

Figure 4. Scatterplots of (a) $\mathrm{Fe}$, (b) $\mathrm{Ba}$, (c) $\mathrm{Sb}$, (d) $\mathrm{Sn}$, (e) $\mathrm{Ga}$, and (f) Mo against $\mathrm{Cu}$ concentrations $\left(\mathrm{ng} \mathrm{m}^{-3}\right)$ in different sizesegregated particles observed in Hsuehshan Tunnel.

sion dust and road dust are major sources of many airborne metals through all PM size ranges inside Hsuehshan Tunnel, and combustion processes from vehicle fleets are additional sources of fine- and submicron-particle-bound metals.

\subsection{Fingerprinting ratios of traffic-derived metals}

$\mathrm{Cu}$ is used as an indicator for wear debris, and the ratios of wear-derived elements to $\mathrm{Cu}$ obtained by the linear regression approach can be applied to determine the contribution of specific metals from wear debris in the urban atmosphere. Figure 4 presents the scatterplots of $\mathrm{Fe}, \mathrm{Ba}, \mathrm{Sb}, \mathrm{Sn}$, $\mathrm{Ga}$, and $\mathrm{Mo}$ against $\mathrm{Cu}$ in $\mathrm{PM}_{1}, \mathrm{PM}_{1-1.8}$, and $\mathrm{PM}_{1.8-10}$ at the two sites. These elements had strong correlations $(r>0.9)$, and these ratios were constant in different size-resolved PM, strongly suggesting that these ratios can be applied as good fingerprinting ratios of wear emissions. The mean mass ratios of $\mathrm{Fe} / \mathrm{Cu}, \mathrm{Ba} / \mathrm{Cu}, \mathrm{Sb} / \mathrm{Cu}, \mathrm{Sn} / \mathrm{Cu}$, and $\mathrm{Ga} / \mathrm{Cu}$ were 14 , $1.05,0.16,0.10$, and 0.03 , respectively. Table 4 compares our ratios to those established by other tunnel studies. The ratios of $\mathrm{Fe} / \mathrm{Cu}$ held around 14 to 15 over all sizes in the present work, which agrees with that (14) acquired by dynamometer tests (Sanders et al., 2003) and is also comparable to those observed in different tunnels (Gillies et al., 2001; Fabretti et al., 2009; Cheng et al., 2010b; Pio et al., 2013). However, the $\mathrm{Fe} / \mathrm{Cu}$ ratio is also significantly distinct from those (37 to 60) found in other tunnels; this difference may have arisen from discrepancies in ingredients of brake pads and in driving conditions (Garg et al., 2000). Ba / $\mathrm{Cu}$ ratios of 0.8-1.1 were similar to those found in Europe but slightly lower than that (> 2) found in the United States. Our $\mathrm{Sb} / \mathrm{Cu}$ ratio of 0.16 is consistent with the result obtained in Hong Kong but lower than that (0.76 to 0.88 ) occasionally measured in American countries (Gillies et al., 2001; Mancilla and Menodza, 2012). In Japan, Iijima et al. (2007), with the use of dynamometer tests, reported $\mathrm{Sb} / \mathrm{Cu}$ ratios ranging from 0.05 to 0.11 for different brake pads. They also pointed out that $\mathrm{Sb}$-free brake pads have been utilized recently in Japanese passenger cars. According to the Taiwan Transportation Vehicle Manufactures Association 44 and $13 \%$ of vehicle fleets in Taiwan are Japanese and American cars, respectively. The abundance of Japanese cars in Taiwan may have caused the lower $\mathrm{Sb} / \mathrm{Cu}$ values in this work. For the Mo-against-Cu scatterplot, two slopes are obtained: 0.05 for coarse and fine particles and 0.12 for particles with aerodynamic diameter less than $0.56 \mu \mathrm{m}$. The enhancement of Mo in these submicron particles is perhaps attributed to an additional source of Mo such as diesel exhausts (Kuo et al., 2009). Previous studies show that the ratio of $\mathrm{V} / \mathrm{Ni}$ has been widely used as a fingerprinting ratio of specific anthropogenic origins. For example, heavy oil combustion shows a narrow range of $\mathrm{V} / \mathrm{Ni}$ ratio (3 to 4) (Hedberg et al., 2005; Mazzei et al., 2008). Combustion origins from gasoline and diesel vehicles have smaller V / Ni ratios (<2.0) (Qin et al., 1997; Watson et al.,, 2001). On the other hand, small quantities of $\mathrm{V}$ and $\mathrm{Ni}$ are also found in soil with a V / Ni ratio of $<1.5$ (Hsu et al., unpublished data). In this work, $\mathrm{V} / \mathrm{Ni}$ ratios were typically lower than 2.0 in fine and submicron PM; the ratios were alternatively acquired directly from their mass concentrations (instead of linear regression) because $\mathrm{V}$ is not strongly correlated with $\mathrm{Ni}(r<0.5$, Tables 2 and S3) in three different sizes. In fine and submicron PM, the lower V / Ni ratios with higher EF value (>10) for both elements suggest that they were contributed mostly by oil combustion from traffic fleets. In coarse PM, a low V / Ni ratio $(<2)$ with a low EF value $(\sim 2)$ for $\mathrm{V}$ indicates that $\mathrm{V}$ was associated with soil origins; however, high $\mathrm{EF}$ for $\mathrm{Ni}$ suggests that $\mathrm{Ni}$ was contributed by combustion sources. The $\mathrm{Pb} / \mathrm{Cu}$ ratios in the tunnel particles averaged at 0.07 , which is much lower than those (much higher than unity) usually observed in ambient air (Fang et al., 2005). In addition, the tunnel particles had $\mathrm{As} / \mathrm{Sb}$ and $\mathrm{Se} / \mathrm{Sb}$ ratios of 0.1 and 0.05 , respectively, which are also evidently lower than those (around unity) measured in ambient aerosols (Querol et al., 2007). These results imply that 
traffic emissions are not major sources of $\mathrm{Pb}, \mathrm{As}$, and $\mathrm{Se}$ in ambient atmospheres.

Figure 5 illustrates the relationships of La against $\mathrm{Ce}$, $\mathrm{Pr}$, Nd, and Sm. Their correlations weaken with decreasing particle size, suggesting that the REEs in smaller particles were disturbed by certain anthropogenic sources. A ratio of $\mathrm{La} / \mathrm{Ce}$ has been successfully used to distinguish natural sources from anthropogenic origins (Kulkarni et al., 2006). In this work, the $\mathrm{La} / \mathrm{Ce}$ ratios that range from 0.15 to 0.18 and from 0.10 to 0.12 at the inlet and outlet sites, respectively, are significantly lower than that of average crust $(\sim 0.50)$ (Taylor, 1964) and soils $(\sim 0.7)$ (Kulkarni et al., 2006). Such values agree with those of Kulkarni et al. (2006) and Huang et al. (1994), who reported that La / Ce ratios for traffic emissions were 0.20 and 0.13 , respectively. As discussed in Sect. 3.2, the EF values of Ce were mostly higher than unity at both the inlet and outlet sites, with even some of the values being 1 order of magnitude higher (Fig. 3), revealing that soil dust is not the sole source of Ce. Thus, the low $\mathrm{La} / \mathrm{Ce}$ values found in the present study could be attributed to an additional supply of $\mathrm{Ce}$ from vehicular emissions.

\section{Summary and concluding remarks}

Size-fractionated aerosol samples were collected in Hsuehshan Tunnel to characterize particulate metals emitted by vehicle fleets. A total of 36 elements were analyzed by ICP-MS. Compared to the entrance, enhanced concentrations for most metals at the exit are due to the piston effect. With regard to enrichment factor, correlation matrix, and principal component analysis, the analyzed metals were categorized into three groups, namely, wear abrasion $(\mathrm{Cu}, \mathrm{Cd}, \mathrm{Cu}, \mathrm{Fe}, \mathrm{Ga}, \mathrm{Mn}, \mathrm{Mo}, \mathrm{Sb}$, and $\mathrm{Sn})$, resuspended dust ( $\mathrm{Ca}, \mathrm{Mg}, \mathrm{K}$, and $\mathrm{Rb}$ ), and pipe emissions ( $\mathrm{Zn}, \mathrm{Pb}$, and $\mathrm{V}$ in fine mode). Size distributions of these elements were significantly different because of their origins. For wear-related metals and geological elements, a mono-modal size distribution was found and the major peak shifted from the range of $3.2-5.6 \mu \mathrm{m}$ at the entrance to the range of $1-1.8 \mu \mathrm{m}$ at the exit. However, elements attributed to combustion sources were predominant mainly in submicron particles and peaked at $0.56-1.0 \mu \mathrm{m}$ at the inlet site and at $0.18-0.32$ or $0.32-0.56 \mu \mathrm{m}$ at the outlet site. By adopting $\mathrm{Cu}$ as an indicator element of wear debris, fingerprinting ratios were constructed, including $\mathrm{Fe} / \mathrm{Cu}, \mathrm{Ba} / \mathrm{Cu}, \mathrm{Sb} / \mathrm{Cu}$, $\mathrm{Sn} / \mathrm{Cu}$, and $\mathrm{Ga} / \mathrm{Cu}$. These ratios can effectively apportion the source of specific elements in urban environments from wear abrasion.

In this work, we characterized traffic-derived PM metals using a tunnel study. The data would be useful for future studies on traffic emission inventory and health effects, especially for submicron PM. Wear abrasion appeared to be a major source of specific toxic elements. While the government focuses on exhaust emission control, the contribution
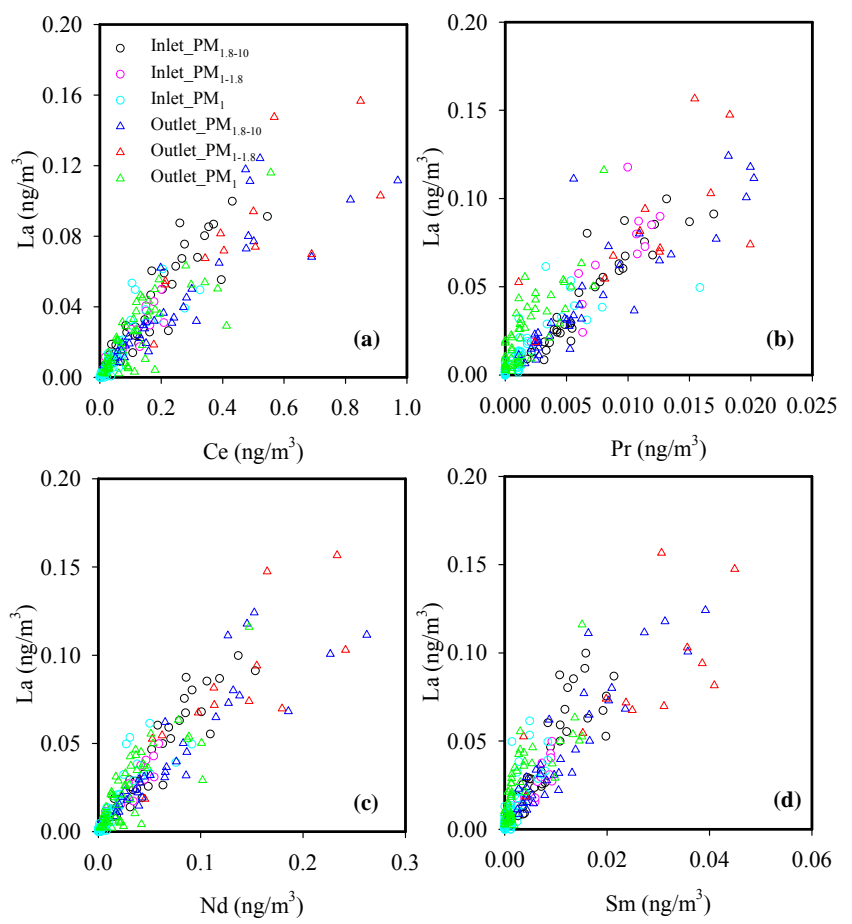

Figure 5. Scatterplots of La and (a) Ce, (b) $\mathrm{Pr}$, (c) $\mathrm{Nd}$, and (d) $\mathrm{Sm}$ concentrations $\left(\mathrm{ng} \mathrm{m}^{-3}\right)$ in different size-segregated particles observed in Hsuehshan Tunnel.

of wear from brake linings and tires should not be ignored. Thus, stringent implementations of measures for reducing wear emissions are needed in the future.

\section{The Supplement related to this article is available online at doi:10.5194/acp-15-4117-2015-supplement.}

Acknowledgements. This project is part of the "Development of Analytical Tools for Measuring and Characterizing Nanomaterials in the Environment" (EPA-101-1602-02-08 and EPA-102-1602-0201 ) and was financially supported by the Environmental Analysis Laboratory of the Environmental Protection Administration in Taiwan. We would like to thank the Directorate General of Highways, MOTC, Taiwan, for supporting the sampling collection in Hsuehshan Tunnel and for providing related information.

Edited by: H. Saathoff 


\section{References}

Abu-Allaban, M., Coulomb, W., Gertler, A. W., Gillies, J., Pierson, W. R., Rogers, C. F., Sagebiel, J. C., and Tarnay, L.: Exhaust particle size distribution measurements at the Tuscarora Mountain Tunnel, Aerosol Sci. Tech., 36, 771-789, doi:10.1080/02786820290038401, 2002.

Adachi, K. and Tainosho, Y.: Characterization of heavy metal particles embedded in the tire dust, Environ. Int., 30, 1009-1017, doi:10.1016/j.envint.2004.04.004, 2004.

Agarwal, A. K., Gupta, T., Bothra, P., and Shukla, P. C.: Emissions profiling of diesel and gasoline cars at a city traffic junction, Particuology, 18, 186-193, doi:10.1016/j.partic.2014.06.008, 2015.

Amato, F., Karanasiou, K., Moreno, T., Alastuey, A., Orza, J. A. G., Lumbreras, J., Borge, R., Boldo, E., Linares, C., and Querol, X.: Emission factors from road dust resuspension in a Mediterranean freeway, Atmos. Environ., 61, 580-587, doi:10.1016/j.atmosenv.2012.07.065, 2012.

Birmili, W., Allen, A. G., Bary, F., and Harrison, R.M.: Trace metal concentrations and water solubility in size-fractionated atmospheric particles and influence of road traffic, Environ. Sci. Technol., 40, 1144-1153, doi:10.1021/es0486925, 2006.

Brauer, M., Hoek, G., Vliet, V. P., Meliefste, K., Fischer, P. H., Wijga, A., Koopman, L. P., Neijens, H. J., Gerritsen, J., Kerkhof, M., Heinrich, J., Bellander, T., and Brunekreef, B.: Air pollution from traffic and the development of respiratory infections and asthmatic and allergic symptoms in children, Am. J. Resp. Crit. Care, 166, 1092-1098, doi:10.1164/rccm.200108-007OC, 2002.

Brito, J., Rizzo, L. V., Herckes, P., Vasconcellos, P. C., Caumo, S. E. S., Fornaro, A., Ynoue, R. Y., Artaxo, P., and Andrade, M. F.: Physical-chemical characterisation of the particulate matter inside two road tunnels in the São Paulo Metropolitan Area, Atmos. Chem. Phys., 13, 12199-12213, doi:10.5194/acp-1312199-2013, 2013.

Cadle, S. H., Mulawa, P. A., Ball, J., Donase, C., Weibel, A., Sagebiel, J. C., Knapp, K. T., and Snow, R.: Particulate emission rates from in use high emitting vehicles recruited in Orange County, California, Environ. Sci. Technol., 31, 3405-3412, doi:10.1021/es9700257, 1997.

Cadle, S. H., Mulawa, P. A., Hunsanger E. C., Nelson, K., Ragazzi, R. A., Barrett, R., Gallagher, G. L., Lawson, D. R., Knapp, K. T., and Snow, R.: Composition of light-duty motor vehicle exhaust particulate matter in the Denver, Colorado area, Environ. Sci. Technol., 33, 2328-2339, doi:10.1021/es9810843, 1999.

Cal-Prieto, M. J., Carlosena, A., Andrade, J. M., Martinez, M. L., Muniategui, S., Lopez-Mahia, P., and Prada, D.: Antinomy as a tracer of the anthropogenic influence on soil and estuarine sediments, Water Air Soil Poll., 129, 333-348, doi:10.1023/A:1010360518054, 2001.

Cassee, F. R., van Balen, E. C., Singh, C., Green, D., Muijser, H., Weinstein, J., and Dreherk, K.: Exposure, health and ecological effects review of engineered nanoscale cerium and cerium oxide associated with its use as a fuel additive, Crit. Rev. Toxicol., 41, 213-229, doi:10.3109/10408444.2010.529105, 2011.

Chang, S.-C., Lin, T.-H., and Lee, C.-T.: On-road emission factors from light-duty vehicles measured in Hsuehshan Tunnel $(12.9 \mathrm{~km})$, the longest tunnel in Asia, Environ. Monit. Assess., 153, 187-200, doi:10.1007/s10661-008-0348-9, 2009.

Chen, S.-C., Tsai, C. J., Chou, Charles C.-K., Roam, G.-D., Cheng, S.-S., and Wang, Y.-N.: Ultrafine particles at three different sampling locations in Taiwan, Atmos. Environ., 44, 553-540, doi:10.1016/j.atmosenv.2009.10.044, 2010.

Cheng, Y.-H., Liu, Z.-S., and Chen, C.-C.: On-road measurements of ultrafine particle concentration profiles and their size distributions inside the longest highway tunnel in Southeast Asia, Atmos. Environ., 44, 763-772, doi:10.1016/j.atmosenv.2009.11.040, 2010a.

Cheng, Y., Lee, S. C., Ho, K. F., Chow, J. C., Watson, J. G., Louie, P. K. K., Cao, J. J., and Hai, X.: Chemically-speciated on road $\mathrm{PM}_{2.5}$ motor vehicle emission factors in Hong Kong, Sci. Total. Environ., 408, 1621-1627, doi:10.1016/j.scitotenv.2009.11.061, 2010b.

Chiang, H.-L. and Huang, Y.-S.: Particulate matter emissions from on-road vehicles in a freeway tunnel study, Atmos. Environ., 43, 4014-4022, doi:10.1016/j.atmosenv.2009.05.015, 2009.

Councell, T. B., Duckenfield K. U., Landa, E. R., and Callender, E.: Tire-wear particles as a source of $\mathrm{Zn}$ to the environment, Envion. Sci. Technol., 38, 4206-4214, doi:10.1021/es034631f, 2004.

Dall'Osto, M., Querol, X., Amato, F., Karanasiou, A., Lucarelli, F., Nava, S., Calzolai, G., and Chiari, M.: Hourly elemental concentrations in $\mathrm{PM}_{2.5}$ aerosols sampled simultaneously at urban background and road site during SAPUSS - diurnal variations and PMF receptor modelling, Atmos. Chem. Phys., 13, 43754392, doi:10.5194/acp-13-4375-2013, 2013.

Defino, R. J., Siotuas, C., and Malik, S.: Potential role of ultrafine particles in associations between airborne particle mass and cardiovascular health, Environ. Health Persp., 113, 934-938, doi:10.1289/ehp.7938, 2005.

Degaffe, F. S. and Turner, A.: Leaching of zinc from tire wear particles under simulated estuarine conditions, Chemosphere, 85, 738-743, doi:10.1016/j.chemosphere.2011.06.047, 2011.

Fabretti, J.-F., Sauret, N., Gal, J.-F., Maria, P.-C., and Schärer, U.: Elemental characterization and sources identification of $\mathrm{PM}_{2.5}$ using Positive Matrix Factorization: the Malraux road tunnel, Nice, France, Atmos. Res., 94, 320-329, doi:10.1016/j.atmosres.2009.06.010, 2009.

Fang G.-C., Wu, Y.-S., Huang, S.-H., and Rau, J.-Y.: Review of atmospheric metallic elements in Asia during 2000-2004, Atmos. Environ., 39, 3003-3013, doi:10.1016/j.atmosenv.2005.01.042, 2005.

Funasaka, K., Miyazaki, T., Kawaraya, T., Tsuruho, K., and Mizuno, T.: Characteristics of particulates and gaseous pollutants in a highway tunnel, Environ. Pollut., 102, 171-176, doi:10.1016/S0269-7491(98)00101-8, 1998.

Garg, B. D., Cadle, S. H., Mulawa, P. A., Groblicki, P. J., Laroo, C., and Parr, G. A.: Brake wear particulate matter emissions, Environ. Sci. Technol., 34, 4463-4469, doi:10.1021/es001108h, 2000.

Gillies, J. A., Gertler, A. W., Sagebiel, J. C., and Dippel, W. A.: On-road particulate matter $\left(\mathrm{PM}_{2.5}\right.$ and $\left.\mathrm{PM}_{10}\right)$ emissions in the Sepulveda tunnel, Los Angeles, California, Environ. Sci. Technol., 35, 1054-1063, doi:10.1021/es991320p, 2001.

Grieshop, A. P., Lipsky, E. M., Pekney, N. J., Takahama, S., and Robinson, A. L.: Fine particle emission factors from vehicle in a highway tunnel: effects of fleet composition and season, Atmos. Environ., 40, 287-298, doi:10.1016/j.atmosenv.2006.03.064, 2006.

Harrison, R. M., Jones A. M., Gielt, J., Yin, J., and Green, D. C.: Estimation of the contributions of brake dust, tire wear, and re- 
suspension to nonexhaust traffic particles derived from atmospheric measurements, Environ. Sci. Technol., 46, 6523-6529, doi:10.1021/es300894r, 2012.

He, L. Y., Hu, M., Zhang, Y. H., Huang, X. F., and Yao, T. T.: Fine particle emissions from on-road vehicles in the Zhujiang tunnel, China, Environ. Sci. Technol., 42, 4461-4466, doi:10.1021/es7022658, 2008.

Hedberg, E., Gidhagen, L., and Johansson, C.: Source contributions to $\mathrm{PM}_{10}$ and arsenic concentrations in Central Chile using positive matrix factorization, Atmos. Environ., 39, 549-561, doi:10.1016/j.atmosenv.2004.11.001, 2005.

Hee, K. W. and Filip, P.: Performance ceramic enhanced phenolic matrix brake linings materials for automotive brake linings, Wear, 29, 1088-1096, doi:10.1016/j.wear.2005.02.083, 2005.

Hsu, S.-C., Liu, S. C., Huang, Y. T., Lung, S.-C. Candice, Tsai, F., Tu, C.-Y., and Kao, S.-J.: A criterion for identifying Asian dust events based on Al concentration data collected from northern Taiwan between 2002 to early 2007, J. Geophys. Res., 113, D18306, doi:10.1029/2007JD009574, 2008.

Hsu, S.-C., Liu, S. C., Huang, Y.-T., Chou, C. C. K., Lung, S. S. Candice, Liu, T. H., Tu, J.-Y., and Tsai, F.: Long-range southeastward transport of Asian biosmoke pollution: Signature detected by aerosol potassium in Northern Taiwan, J. Geophys. Res., 114, D14301, doi:10.1029/2009JD011725, 2009.

Hsu, S. C., Liu, S. C., Tsai, F., Engling, G., Lin, I. I., Chou, C. K. C., Kao, S. J., Lung, S. C. C., Chan, C. Y., Lin, S. C., Huang, J. C., Chi, K. H., Chen, W. N., Lin, F. J., Huang, C. H., Kuo, C. L., Wu, T. C., and Huang, Y. T.: High wintertime particulate matter pollution over a offshore island (Kinmen) off Southeastern China: an overview, J. Geophys. Res., 115, D17309, doi:10.1029/2009JD013641, 2010.

Huang, X., Olmez, I., Aras, N. K., and Gordon, G. E.: Emissions of trace elements from motor vehicles: potential marker elements and source composition profile, Atmos. Environ., 28, 1385-1391, doi:10.1016/1352-2310(94)90201-1, 1994.

Iijima, A., Sato, K., Yano, K., Tago, H., Kato, M., Kimura, H., and Furuta, N.: Particle size and composition distribution analysis of automotive brake abrasion dusts for the evaluation of antimony sources of airborne particulate matter, Atmos. Environ., 41, 4908-4919, doi:10.1016/j.atmosenv.2007.02.005, 2007.

Ingo, G. M., D’Uffizi, M., Falso, G., Bultrini, G., and Padeletti, G.: Thermal and microchemical investigation of automotive brake pad wear residues, Thermochim. Acta, 418, 61-68, doi:10.1016/j.tca.2003.11.042, 2004.

Jamriska, M., Morawska, L., Thomas, S., and He, C.: Diesel bus emissions measured in a tunnel study, Environ. Sci. Technol., 38, 6701-6709, doi:10.1021/es030662z, 2004.

Johansson, C., Norman, M., and Burman, L.: Road traffic emission factors for heavy metals, Atmos. Environ., 43, 4681-4688, doi:10.1016/j.atmosenv.2008.10.024, 2009.

Kulkarni, P., Chellam, S., and Fraser, M. P.: Lanthanum and lanthanides in atmospheric fine particles and their apportionment to refinery and petrochemical operations in Houston, TX, Atmos. Environ., 40, 508-520, doi:10.1016/j.atmosenv.2005.09.063, 2006

Kuo, C.-Y., Wang, J.-Y., Chang, S.-H., and Chen, M.-C., Study of metal concentrations in the environment near diesel transport routes, Atmos. Environ., 43, 3070-3076, doi:10.1016/j.atmosenv.2009.03.028, 2009.
Lai, C.-H. and Peng, Y.-P.: Volatile hydrocarbon emissions from vehicles and vertical ventilations in the Hsuehshan traffic tunnel, Taiwan, Environ. Monit. Assess., 184, 4015-4028, doi:10.1007/s10661-011-2240-2, 2012.

Lawrence, S., Sokhi, R., Ravindra, K., Mao, H., Prain, H. D., and Bull, I. D.: Source apportionment of traffic emissions of particulate matter using tunnel measurements, Atmos. Environ., 77, 548-557, doi:10.1016/j.atmosenv.2013.03.040, 2013.

Li, H.-C., Chen, K. S., Lai, C.-H., and Wang, H.-K.: Measurements of gaseous pollutant concentrations in the Hsuehshan traffic tunnel of Northern Taiwan, Aerosol Air Qual. Res., 11, 776-782, doi:10.4209/aaqr.2011.02.0009, 2011.

Lin, C.-C., Chen, S.-J., Huang, K.-L., Hwang, W.-I., ChangChien, G. P., and Lin, W. Y.: Characteristics of metals in nano/ultrafine/fine/coarse particles collected beside a heavily trafficked road, Environ. Sci. Technol., 39, 8113-8125, doi:10.1021/es048182a, 2005.

Lough, G. C., Schauer, J. J., Park, J.-S., Shafer, M. M., Deminter, J. T., and Weinstein, J. P.: Emissions of metal associated with motor vehicle roadways, Environ., Sci. Technol., 39, 826-836, doi:10.1021/es048715f, 2005.

Mancilla, Y. and Mendoza, A.: A tunnel study to characterize $\mathrm{PM}_{2.5}$ emissions from gasoline-powered vehicles in Monterrey, Mexico, Atmos. Environ., 59, 449-460, doi:10.1016/j.atmosenv.2012.05.025, 2012.

Mazzei, F., D’Alessandro, A., Lucarelli, F., Nava, S., Prati, P., Valli, G., and Vecchi, R.: Characterization of particulate matter sources in an urban environment, Sci. Total Environ., 401, 81-89, doi:10.1016/j.scitotenv.2008.03.008, 2008.

Moreno, T., Pérez, N., Reche, C., Martins, C., de Miguel, E., Capdevila, M., Centelles, S., Minguillón, M. C., Amato, F., Alastuey, A., Querol, X., and Gibbson, W.: Subway platform air quality: assessing the influences of tunnel ventilation, train piston effect and station design, Atmos. Environ., 92, 461-468, doi:10.1016/j.atmosenv.2014.04.043, 2014.

Nel, A.: Air pollution-related illness: effects of particle, Science, 308, 804-806, doi:10.1126/science.1108752, 2005.

Ning, Z., Polidori, A., Schauer, J. J., and Sioutas, C.: Emission factors of PM species based on freeway measurements and comparison with tunnel and dynamometer studies, Atmos. Environ., 42, 3099-3114. doi:10.1016/j.atmosenv.2007.12.039, 2008.

Ntziachristos, L., Ning, Z., Geller, M. D., and Sioutas, C.: Particle concentration and characteristics near a major freeway with heavy-duty diesel traffic, Environ. Sci. Technol., 41, 2223-2230. doi:10.1021/es062590s, 2007.

Pio, C., Mirante, F., Oliveira, C., Matos, M., Caseiro, A., Oliveira, C., Querol, X., Alves, C., Martins, N., Cerqueira, M., Camões, F., Silva, H., and Plana, F.: Size-segregated chemical composition of aerosol emissions in an urban road tunnel in Portugal, Atmos. Environ., 71, 15-25, doi:10.1016/j.atmosenv.2013.01.037, 2013.

Qin, Y., Chan, K. C., and Chan, Y. L.: Characteristics of chemical compositions of atmospheric aerosol in Hong Kong, spatial and seasonal distributions, Sci. Total Environ., 206, 25-37, doi:10.1016/S0048-9697(97)00214-3, 1997.

Querol, X., Viana, M., Alastuey, A., Amato, F., Moreno, T., Castillo, S., Pey, J., de la Rosa, J., Sánchez de la Campa, A., Artíñano, B., Salvador, P., García Dos Santos, S., Fernández-Patier, R., Moreno-Grau, S., Negral, L., Minguillón, M. C., Monfort E., Gil, J. I., Inza, A., Ortega, L. A., Santamaría, J. M., and Zabalza, J.: 
Source origin of trace elements in PM from regional background, urban and industrial sites of Spain, Atmos. Environ., 41, 72197231, doi:10.1016/j.atmosenv.2007.05.022, 2007.

Rogge, W. F., Hildemann, L. M., Mazurek, M. A., Cass, G. R., and Simoneit, B. R. T.: Sources of fine organic aerosol. 3. Road dust, tire debris, and organometallic brake lining dustroads as source and sinks, Environ. Sci. Technol., 27, 1892-1904, doi:10.1021/es00046a019, 1993.

Sanders, P. G., Xu, N., Dalka, T. M., and Maricq, M. M.: Airborne brake wear debris: size distributions, composition, and a comparison of dynamometer and vehicle tests, Environ. Sci. Technol., 37, 4060-4069, doi:10.1021/es034145s, 2003.

Shafer, M. M., Toner, B. M., Overdier, J. T., Schauer, J. J., Fakra, S. C., Hu, S., Herner, J. D., and Ayala, A.: Chemical speciation of vanadium in particulate matter emitted from diesel vehicles and urban atmospheric aerosols, Environ. Sci. Technol., 46, 189-195, doi:10.1021/es200463c, 2012.

Sharma, M., Agarwal, A. K., and Bharathi, K. V. L.: Chracterization of exhaust particulates from diesel engine. Atmos. Environ., 39, 3023-3028, doi:10.1016/j.atmosenv.2004.12.047, 2005.

Sternbeck, J., Sjödin, Å., and Andréasson, K.: Metal emissions from road traffic and the influence of resuspension-results from two tunnel studies, Atmos. Environ., 36, 4735-4744, doi:10.1016/S1352-2310(02)00561-7, 2002.

Taheri, S., Khoshgoftarmanesh, A. H., Shariatmadari, H., and Chaney, R. L.: Kinetics of zinc release from ground tire rubber and rubber ash in a calcareous soil as alternatives to $\mathrm{Zn}$ fertilizers, Plant Soil, 341, 89-91, doi:10.1007/s11104-010-0624-7, 2011.

Tanner, P. A., Hoi-Ling, M., and Yu, P. K. N.: Fingerpriting metals in urban street dust in Beijing, Shanghai and Hong Kong, Environ. Sci. Technol., 42, 7111-7117, doi:10.1021/es8007613, 2008.
Taylor, S. R.: Abundance of chemical elements in the continental crust: a new table, Geochim. Cosmochim. Ac., 18, 1273-1285, doi:10.1016/0016-7037(64)90129-2, 1964.

Thorpe, A. and Harrison, R. M.: Sources and properties of nonexhaust particulate matter from road traffic: a review, Sci. Total Environ., 400, 270-282, doi:10.1016/j.scitotenv.2008.06.007, 2008.

Wåhlin, P., Berkowicz, R., and Palmgren F.: Characterization of traffic-generated particulate matter in Copenhagen, Atmos. Environ., 40, 2151-2159, doi:10.1016/j.atmosenv.2005.11.049, 2006.

Wang, Y.-F., Huang, K.-L., Li, C.-T., Mi, H.-H., Luo, J.H., and Tsai, P.-J.: Emissions of fuel metals content from a diesel vehicle engine, Atmos. Environ., 33, 4637-4643, doi:10.1016/j.atmosenv.2003.07.007, 2003.

Watson, J., Chow, J., and Houck, J. E.: $\mathrm{PM}_{2.5}$ chemical source profiles for vehicle exhaust, vegetative burning, geological material and coal burning in Northwestern Colorado during 1995, Chemosphere, 43, 1141-1151, doi:10.1016/S0045-6535(00)00171-5, 2001.

Weingartner, E., Keller, C., Stahel, W. A., Burtscher, H., and Baltensperger, U.: Aerosol emission in a road tunnel, Atmos. Environ., 31, 451-462, doi:10.1016/S1352-2310(96)00193-8, 1997.

Zhang, R., Jing, J., Tao, J., Hsu, S.-C., Wang, G., Cao, J., Lee, C. S. L., Zhu, L., Chen, Z., Zhao, Y., and Shen, Z.: Chemical characterization and source apportionment of $\mathrm{PM}_{2.5}$ in Beijing: seasonal perspective, Atmos. Chem. Phys., 13, 7053-7074, doi:10.5194/acp-13-7053-2013, 2013.

Zhu, C.-S., Chen, C.-C., Cao, J.-J., Tsai, C.-J., Chou, C. C.K., Liu, S.-C., and Roam, G.-D.: Characterization of carbon fractions for atmospheric fine particles and nonoparticles in a highway tunnel, Atmos. Environ., 44, 2668-2673, doi:10.1016/j.atmosenv.2010.04.042, 2010. 